\title{
Assessment of the fatty acid composition of different parts of zebrafish fed diets incorporated with linseed and sunflower oils
}

\author{
A valiação da composição lipídica de diferentes partes de peixe-zebra alimentados com dietas \\ incorporadas com óleos de linhaça e girassol \\ Evaluación de la composición lipídica de diferentes partes del pez cebra alimentado con dietas \\ incorporadas con aceites de linaza y girassol
}

Received: 11/11/2021 | Reviewed: 11/19/2021 | Accept: 11/26/2021| Published: 12/08/2021

Victor Hugo Maldonado da Cruz

ORCID: https://orcid.org/0000-0003-2050-9149

Universidade Estadual de Maringá, Brazil

E-mail: victor.hugo.maldonado.cruz@ gmail.com

Geovane Aparecido Ramos da Silva

ORCID: https://orcid.org/0000-0003-3749-6938

Universidade Estadual de Maringá, Brazil

E-mail: geovane.rsilva21@gmail.com

Matheus Campos Castro

ORCID: https://orcid.org/0000-0002-9918-1491

Universidade Estadual de Maringá, Brazil

E-mail: 1996mcastro@gmail.com

Isadora Boaventura Ponhozi

ORCID: https://orcid.org/0000-0001-7230-161X

Universidade Estadual de Maringá, Brazil

E-mail: isa.ponhozi@gmail.com

Patrícia Magalhães de Souza

ORCID: https://orcid.org/0000-0001-5916-0744

Universidade Estadual de Maringá, Brazil

E-mail: patricia.magalhaes11@hotmail.com

Jesui Vergilio Visentainer

ORCID: https://orcid.org/0000-0003-3412-897X

Universidade Estadual de Maringá, Brazil

E-mail: jesuivv@gmail.com

Oscar Oliveira Santos Júnior

ORCID: https://orcid.org/0000-0002-9631-8480

Universidade Estadual de Maringá, Brazil

E-mail: oliveirasantos.oscardeoliveira@gmail.com

\begin{abstract}
This study aimed to evaluate the fatty acid composition of zebrafish fed diets containing linseed oil compared to sunflower oil. First, diets supplemented with linseed and sunflower were formulated, fish were fed for 40 days, and their parts collected for analysis. Diet composition analysis, extraction and derivatization of fatty acids, gas chromatography analysis, RNA extraction and cDNA synthesis, quantitative real-time polymerase chain reaction (qRT-PCR, and statistical analyses were performed. Linseed oil exhibited an omega-3 rich lipid profile. 18:3n-3 content incorporated into the muscle tissue of fish fed linseed oil was 50\% higher than that fed sunflower oil. This higher amount of 18:3n-3 favored the production of 20:5n-3 and 22:6n-3 fatty acids by synthetic pathways in the organism since these fatty acids were not initially found in the oil composition. Furthermore, in all analyzed parts of zebrafish that were fed linseed oil, concentration of 20:4n-6 were lower, while 20:5n-3 and 22:6n-3 were higher compared to the same parts fed with sunflower oil. PCR expression assay showed no significant difference, indicating that linseed oil diet was not harmful. Thus, this work evidenced that synthesis of essential fatty acids, primarily omega-3 fatty acids, was greater in zebrafish upon consumption of diets supplemented with linseed oil.
\end{abstract}

Keywords: Fish diet; Fatty acid; Lipid analysis; Gas chromatography; PCR.

\section{Resumo}

Este trabalho teve como objetivo avaliar a composição em ácidos graxos de peixes-zebra alimentados com dietas contendo óleo de linhaça em comparação com o óleo de girassol. Primeiramente, as dietas suplementadas com óleo de linhaça e girassol foram formuladas, os peixes receberam a alimentação durante 40 dias e suas partes foram coletadas para análise. Realizou-se análises de composição das dietas, extração e derivatização de ácidos graxos, análise por 
cromatografia gasosa, extração de RNA e síntese de cDNA, reação em cadeia da polimerase quantitativa em tempo real (qRT-PCR) e análise estatística. Após análises, o óleo de linhaça apresentou perfil lipídico rico, principalmente em n-3. A quantidade de ácido graxo 18:3n-3 incorporada ao tecido muscular do peixe que recebeu óleo de linhaça foi $50 \%$ superior ao alimentado com óleo de girassol. Essa maior concentração de 18:3n-3 favoreceu a produção de ácidos graxos 20:5n-3 e 22:6n-3 por vias sintéticas do organismo, uma vez que estes não foram encontrados inicialmente na composição dos óleos. Além disso, em todas as partes analisadas dos peixes-zebra que receberam ração de óleo de linhaça, as concentrações de 20:4n-6 foram inferiores, enquanto 20:5n-3 e 22:6n-3 foram superiores em comparação aos alimentos com ração de óleo de girassol. O ensaio de expressão PCR não apresentou diferença significativa, indicando que a ração com óleo de linhaça não era prejudicial. Desta forma, o trabalho evidenciou que a síntese de ácidos graxos essenciais, principalmente dos ácidos graxos n-3, é melhor estabelecida com o consumo de dieta adicionada de óleo de linhaça para peixe-zebra.

Palavras-chave: Ração de peixes; Ácido graxo; Análise lipídica; Cromatografia gasosa; PCR.

\section{Resumen}

El objetivo de este estudio era evaluar la composición de ácidos grasos del pez cebra alimentado con dietas que contenían aceite de linaza en comparación con el aceite de girasol. En primer lugar, se formularon dietas suplementadas con linaza y girasol, se alimentó a los peces durante 40 días y se recogieron sus partes para su análisis. Se realizó un análisis de la composición de la dieta, la extracción y derivatización de los ácidos grasos, el análisis por cromatografía de gases, la extracción de ARN y la síntesis de ADNc, la reacción en cadena de la polimerasa en tiempo real (qRT-PCR) y los análisis estadísticos. El aceite de linaza mostró un perfil lipídico rico en omega-3. El contenido de 18:3n-3 incorporado en el tejido muscular de los peces alimentados con aceite de linaza fue un 50\% superior al de los alimentados con aceite de girasol. Esta mayor cantidad de 18:3n-3 favoreció la producción de ácidos grasos 20:5n-3 y 22:6n-3 por vías sintéticas en el organismo, ya que estos ácidos grasos no se encontraban inicialmente en la composición del aceite. Además, en todas las partes analizadas del pez cebra que fue alimentado con aceite de linaza, la concentración de 20:4n-6 fue menor, mientras que la de 20:5n-3 y 22:6n-3 fue mayor en comparación con las mismas partes alimentadas con aceite de girasol. El ensayo de expresión por PCR no mostró diferencias significativas, lo que indica que la dieta con aceite de linaza no era perjudicial. Así pues, este trabajo evidenció que la síntesis de ácidos grasos esenciales, principalmente de ácidos grasos omega-3, fue mayor en el pez cebra al consumir dietas suplementadas con aceite de linaza.

Palabras clave: Dieta de pescado; Ácidos grasos; Análisis de lipídios; Cromatografía de gases; PCR.

\section{Introduction}

Polyunsaturated fatty acids are essential to cell membranes constituents. Involved in numerous diseases prevention, it is responsible for adequate blood coagulation, blood pressure regulation, inflammation control in cases of infections and lesions, and immune system strengthening (Lordan et al., 2020; Djuricic \& Calder, 2021; Gammone et al., 2019).

The concentration of certain fatty acids in the cell's membrane is dependent, in part, on the fatty acid content of the animal's diet. Some animal species, including fish, are capable of synthesizing most of their fatty acids. Nevertheless, 18:3n-3 and 18:2n-6 fatty acids must be obtained through a balanced diet; therefore, both are entitled essential fatty acids (Broughton, Tocher \& Betancor, 2020; Zhang et al, 2019; Zhukova, 2019). The 18:3n-3 is present in plants and marine animals, although superior concentration could be found in linseed, chia, and perilla grains; and 18:2n-6 is encountered in vegetable oils, such as sunflower, corn, and soybean oils (Perini et al., 2010; Sargi et al., 2013; Simopoulos, Serhan \& Bazinet, 2021).

The 18:2n- 6 fatty acid is the precursor of the metabolic pathway of the n-6 polyunsaturated fatty acid family, and through it, is possible to synthesize 20:4n-6 fatty acid; the main precursor of eicosanoids production, which in ideal amounts, improves the immune system response and stress resistance (Simopoulos, Serhan \& Bazinet, 2021; Pérez et al., 2021). Conversely, at elevated concentrations, it may offer toxic properties to the organism, and promotes competition among enzymes responsible for activating the metabolic pathway of the n-3 polyunsaturated fatty acid family, destabilizing essential fatty acid production, such as 20:5n-3 and 22:6n-3 fatty acids, produced from 18:3n-3 (Simopoulos, Serhan \& Bazinet, 2021; Balić et al., 2020).

Due to the demand for research concerning the nutritional quality of animal feed, efforts are focused on discovering natural sources abundant in bioactive compounds, including essential fatty acids (Adel et al., 2016; Carbonera et al., 2014). Bioactive incorporation achievement in feed production depends on several aspects, such as physicochemical stability of 
compounds during feed manufacturing procedures, thermal degradation of bioactive during extrusion stage, components oxidative stability, and compounds bioavailability are examples that directly influence it (Nehra et al, 2020; Pérez-Palacios et al., 2019).

Zebrafish (Danio rerio), a small freshwater tropical teleost, measuring nearly $5 \mathrm{~cm}$ in adulthood, is a living experimental model applied effectively for research in diverse scientific areas. Publications relating to it have increased in recent years and aroused scientific community attention. The species has appealed to researchers' interest by several motives: small size, easy maintenance, breeding viability, high reproductive rate, and similar mammals sequenced genome; closely 70 $\%$ of human genes have an ortholog in the zebrafish genome, subsequently, it is considered an excellent experimental model for research development (Stevens, Reed \& Hawkins, 2021; Verma et al., 2021; Canedo \& Rocha, 2020).

Although zebrafish is a model extensively applied in research relating to genetics, mutation, and cloning to comprehend embryonic progress and diseases mechanisms, the potential incorporation of bioactive for nutrition is minor investigated. Given the important role essential fatty acids play in the health of animals along with the scarcity of studies employing potential incorporation of bioactive for zebrafish nutrition, this work aimed to evaluate the potential of a linseedsupplemented diet in enhancing the lipid quality of zebrafish by increasing the content of omega- 3 fatty acids.

\section{Methodology}

\subsection{Chemicals and standards}

Fatty acid methyl esters (FAMEs 189-19) standard mixture, sodium hydroxide, methanol, sulfuric acid, heptane, and methyl tricosanoate (23:0me) were purchased from Millipore-Sigma ${ }^{\circledR}$, RNA Later from Sigma-Aldrich, QIAmp RNA Blood Mini Kit from QIAGEN, and RT Kit Plus from Nanogen Advanced Diagnostics (Turin, Italy).

\subsection{Diets}

The diets were formulated according to Siccaedi et al. (2009) and supplemented with $5 \%$ of sunflower and linseed oils, separately (Table 1). 
Table 1. Feed ingredients of experimental diets.

\begin{tabular}{|c|c|c|}
\hline \multirow{2}{*}{ Ingredients } & \multicolumn{2}{|c|}{ 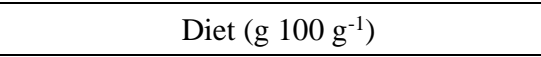 } \\
\hline & Sunflower & Linseed \\
\hline Sunflower oil & 5.00 & - \\
\hline Linseed oil & - & 5.00 \\
\hline Soybean meal & 39.37 & 39.37 \\
\hline Corn gluten & 25.10 & 25.10 \\
\hline Corn grain & 11.96 & 11.96 \\
\hline Rice sauerkraut & 5.00 & 5.00 \\
\hline Wheat gluten & 5.00 & 5.00 \\
\hline Dicalcium phosphate & 3.85 & 3.85 \\
\hline Soybean protein isolate & 3.00 & 3.00 \\
\hline Supplement (vitamin and mineral) $*$ & 1.00 & 1.00 \\
\hline L-threonine & 0.23 & 0.23 \\
\hline Antifungal & 0.20 & 0.20 \\
\hline Choline chloride & 0.10 & 0.10 \\
\hline Vitamin C & 0.10 & 0.10 \\
\hline L-tryptophan & 0.06 & 0.06 \\
\hline DL-methionine & 0.01 & 0.01 \\
\hline Antioxidant & 0.02 & 0.02 \\
\hline
\end{tabular}

*Vitamin and mineral supplement composed of: vitamin A (500 IU), vitamin D3 (200 IU), vitamin E (5 mg), vitamin K3 (1000 mg), vitamin B1 (1.5 mg), vitamin B2 (1.5 mg), vitamin B6 (1.5 mg), vitamin B12 (4 mg), folic acid (500 mg), calcium pantothenate (4000 mg), vitamin C $(15 \mathrm{mg})$, biotin $(50 \mathrm{mg})$, inositol $(10 \mathrm{mg})$, nicotinamide $(7 \mathrm{mg})$, choline $(40 \mathrm{mg})$, cobalt $(10 \mathrm{mg})$, copper $(500 \mathrm{mg})$, iron $(5 \mathrm{mg})$, iodine $(50$ $\mathrm{mg})$, manganese $(1.5 \mathrm{mg})$, selenium $(10 \mathrm{mg})$, zinc $(5 \mathrm{mg})$.

Source: Siccaedi et al. (2009) with modifications.

\subsection{Zebrafish}

Male and female zebrafish (Danio rerio) with five-week-old were used. One-hundred and fifty fishes were apportioned equally and randomly in two tanks with 40 liters capacity. Each group received one type of diet for 40 days, 4 times a day. After the feeding period, zebrafishes were euthanized; head, eyes, and muscle tissue were collected, and it was reserved in polyethylene bags and stored at $-18{ }^{\circ} \mathrm{C}$ until analysis. At the beginning of each analysis, samples were allowed to equilibrate to RT and homogenized. The research was approved by the Animal Ethics Committee from the State University of Maringa (Process 097/2014).

\subsection{Proximate composition of experimental diets}

Moisture content was determined according to AOAC Official Method 930.15; ash content according to AOAC Official Method 942.05 and crude protein was measured according to AOAC Official Method 960.52, using a factor of 6.25 to convert percentage nitrogen to percentage protein (AOAC, 200). Total lipid content was determined according to the procedure described by Bligh and Dyer (1959). Nifext fractions were estimated by difference, while energy values of diets were calculated based on conversion factors (Nifext fraction $4 \mathrm{kcal} \mathrm{g}^{-1}$; crude protein $4 \mathrm{kcal} \mathrm{g}^{-1}$; total lipids 9 kcal $\mathrm{g}^{-1}$ ) according to the Health Ministry of Brazil (Brasil, 1998).

\subsection{Lipid extraction and fatty acids derivatization for gas chromatography analysis}

Lipid extraction and fatty acids derivatization were performed according to Figueiredo et al. (2016) Initially, approximately $100 \mathrm{mg}$ of triturated sample was weighed in a test tube, $2.0 \mathrm{~mL}$ of sodium hydroxide $\left(1.5 \mathrm{~mol} \mathrm{\textrm {L } ^ { - 1 }}\right.$ in methanol) 
was added. Subsequently, the sample was crushed with a glass stirring rod, test tubes were placed in an ultrasonic bath (EcoSonics $\left.{ }^{\circledR} \mathrm{Q} 5.9 / 25\right)$ for 5 minutes. Posteriorly, $2.0 \mathrm{~mL}$ of sulfuric acid $\left(1.5 \mathrm{~mol} \mathrm{~L}^{-1}\right.$ in methanol) was added, the test tube was placed in an ultrasonic bath for 5 minutes. After reaction in ultrasound, $1 \mathrm{~mL}$ of heptane was added, and tubes were vortexed for $30 \mathrm{~s}$ and centrifuged at $2000 \mathrm{rpm}$ for 1 minute. Lastly, $500 \mu \mathrm{L}$ of internal standard (23:0me) with $1 \mathrm{mg} \mathrm{mL}^{-1}$ concentration was added, and the upper phase was collected for analysis on gas chromatography.

\subsection{Gas chromatography analysis}

Fatty acids quantification was performed according to Figueiredo et al. (2016). Chromatographic analysis was carried out on gas chromatography (Thermo ${ }^{\circledR}$ Scientific) equipped with flame ionization detector, automatic sample injection system, and fused silica CP-7420 (Select FAME) capillary column (100 m size, $0.25 \mathrm{~mm}$ i.d. and $0.25 \mu \mathrm{m}$ cyanopropyl). Operation parameters were: injector temperature at $230{ }^{\circ} \mathrm{C}$, detector temperature at $250{ }^{\circ} \mathrm{C}$, column temperature at $165{ }^{\circ} \mathrm{C}$ for $18 \mathrm{~min}$, ramped to $235{ }^{\circ} \mathrm{C}\left(4{ }^{\circ} \mathrm{C} \mathrm{min}{ }^{-1}\right)$ for $20 \mathrm{~min}$. Gas flow rates used were $1.2 \mathrm{~mL} \mathrm{~min}^{-1}$ for $\mathrm{H}_{2}$ (carrier gas), $30 \mathrm{~mL} \mathrm{~min}^{-1}$ for $\mathrm{N}_{2}$ (make-up gas), and 30 and $300 \mathrm{~mL} \mathrm{~min}^{-1}$ for FID gas $\mathrm{H}_{2}$ and synthetic air, respectively. The sample was injected (1 $\mu \mathrm{L}$ ) in split mode with a 40:1 split ratio. FAMEs were identified by comparison of retention times of sample constituents with Sigma FAMEs standard. Theoretical flame ionization detector correction factor values were used in calculations to obtain fatty acid concentration values according to Visentainer (2012) and results were expressed as mol of fatty acid $\mathrm{g}^{-1}$ of sample.

\subsection{RNA extraction and cDNA synthesis}

After the feeding period, zebrafish livers of both diets were collected and maintained in RNAlater ${ }^{\circledR}$ (Sigma-Aldrich) solution at $4{ }^{\circ} \mathrm{C}$ until RNA isolation. Total RNA was extracted using QIAmp RNA Blood Mini Kit (QIAGEN) according to the manufacturer's specifications. Total RNA concentration and purity were determined by NanoDrop 2000c Spectrophotometer (Thermo Scientific) using a $260 / 280 \mathrm{~nm}$ absorbance ratio. Purified total RNA (1 $\mu \mathrm{g}$ ) was transcribed to first-strand cDNA using RT Kit Plus (Nanogen) according to manufacturer's instructions.

\subsection{Quantitative real-time polymerase chain reaction (qRT-PCR)}

Primers sequences chosen for gene expression analysis in zebrafish in liver tissue were based on Jaya-Ramet et al. (2008) as exposed in Table 2.

Table 2. Primer sequences used for analyzing gene expression in liver tissue.

\begin{tabular}{lccc}
\hline & \multicolumn{2}{c}{ GBA $^{\text {b }}$} & \multicolumn{2}{c}{ Primer sequence (5' to 3') } & Reverse \\
\cline { 2 - 4 } TG $^{\text {a }}$ & & \multicolumn{2}{c}{ Forward } \\
\cline { 2 - 4 } $\begin{array}{l}\text { Desaturase } \\
\text { Fadsd6) }\end{array}$ & AF309556 & CCGTATCTGTGGTGGAAGAAG & AAGTTTGAGAAGAGCAGGATGAG \\
$\begin{array}{l}\text { Elongase } \\
\text { (elovl5) }\end{array}$ & AF532782 & CCGTATCTGTGGTGGAAGAAG & AAGTTTGAGAAGAGCAGGATGAG \\
$\beta$-actin & AF057040 & CCGTGACATCAAGGAGAAGCT & TCGTGGATACCGCAAGATTCC \\
\hline
\end{tabular}

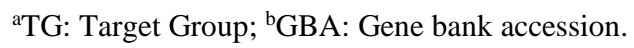

Source: Jaya-Ramet et al. (2008). 
Real-time reactions were performed with $1 \mu \mathrm{L}$ of first-strand cDNA was subject to reaction mixture with $5 \mu \mathrm{L}$ of SYBR $^{\circledR}$ Green RT-PCR Reaction Mix, $0.16 \mu \mathrm{L}$ of each primer $\left(0.1 \mathrm{~mol} \mathrm{~L}^{-1}\right)$, and $3.68 \mu \mathrm{L}$ of free-RNA water. $\beta$-actin was used to normalize the expression of the selected gene. qReal-time PCR was performed with StepOne ${ }^{\mathrm{TM}}$ Real-Time PCR System (Applied Biosystems). The PCR program used was an initial denaturation at $95{ }^{\circ} \mathrm{C}$ for 5 min; amplification cycles of $95{ }^{\circ} \mathrm{C}$ for $5 \mathrm{~s}, 60{ }^{\circ} \mathrm{C}$ for $15 \mathrm{~s}, 72{ }^{\circ} \mathrm{C}$ for $20 \mathrm{~s}$. Amplification plots indicating fluorescence intensity at each cycle were obtained from which $\mathrm{Ct}$ values were measured for each sample. PCRs were run in triplicates for each sample and Ct averages were obtained, followed by normalization to the average of $\beta$-actin (reference gene), following $2^{\Delta \Delta \mathrm{Ct}}$ method (Livak \& Schmittgen, 2011).

\subsection{Statistical Analysis}

Statistical and principal components analysis (PCA) were carried out using Statistica ${ }^{\circledR}$ software 7.0 version. Results were assessed through analysis of variance (ANOVA) and t-test with $5 \%$ of probability.

\section{Results and Discussion}

\subsection{Diets}

Diets were formulated to provide sufficient nutritional amounts for zebrafish to grow healthily. Therefore, proximate composition and fatty acid quantification of diets were determined, and results are presented in Table 3.

Table 3. Proximate composition and fatty acids quantification of diets.

\begin{tabular}{|c|c|c|}
\hline \multicolumn{3}{|c|}{ Proximate composition $\left({\left.\mathrm{g} 100 \mathrm{~g}^{-1}\right)}\right.$} \\
\hline & Sunflower & Linseed \\
\hline Moisture & $7.84(2.68)$ & $7.36(3.40)$ \\
\hline Ash & $5.27(0.57)$ & $5.31(0.19)$ \\
\hline Crude protein & $28.34(2.40)$ & $28.33(2.33)$ \\
\hline Total lipids & $6.02(5.98)$ & $5.72(0.52)$ \\
\hline Nifext & $52.53(1.05)$ & $53.28(0.69)$ \\
\hline Energy $\left(\mathrm{kcal} 100 \mathrm{~g}^{-1}\right)$ & $377.66(0.31)$ & $377.91(0.20)$ \\
\hline \multicolumn{3}{|c|}{ Fatty acids quantification ( $\mu \mathrm{mol}$ of fatty acid $\mathrm{g}^{-1}$ of sample) } \\
\hline 16:0 & $11.40(2.93)$ & $12.50(1.55)$ \\
\hline 18:0 & $2.81(2.17)$ & $3.75^{*}(1.38)$ \\
\hline $18: 1 n-7$ & $0.74(5.36)$ & $0.91(4.68)$ \\
\hline $18: 1 n-9$ & $39.40^{*}(3.49)$ & $28.60(2.36)$ \\
\hline $18: 2 n-6$ & $50.70 *(5.26)$ & $37.40(1.66)$ \\
\hline $18: 3 n-3$ & $2.09(1.38)$ & $38.90^{*}(2.68)$ \\
\hline$\Sigma$ SFA & $14.21(0.06)$ & $16.25^{*}(0.57)$ \\
\hline$\Sigma$ MUFA & $40.14^{*}(9.16)$ & $29.51(1.52)$ \\
\hline$\Sigma$ PUFA & $52.79(3.54)$ & $76.30 *(0.39)$ \\
\hline$\Sigma \mathrm{n}-6$ & $50.70 *(5.26)$ & $37.40(1.66)$ \\
\hline$\Sigma \mathrm{n}-3$ & $2.09(1.38)$ & $38.90^{*}(2.68)$ \\
\hline$\Sigma \mathrm{PUFA} / \Sigma \mathrm{SFA}$ & $3.71(2.12)$ & $4.69^{*}(4.92)$ \\
\hline$\Sigma \mathrm{n}-6 / \Sigma \mathrm{n}-3$ & $24.26^{*}(4.20)$ & $0.96(5.67)$ \\
\hline
\end{tabular}

Results expressed as mean (coefficient of variation; \%) for analysis in three replicates. * Means with a significant difference by t-test (P $<0.05)$. Nifext: nitrogen-free extract; $\Sigma$ SFA: sum of saturated fatty acids; $\Sigma$ MUFA: sum of monounsaturated fatty acids; $\Sigma$ PUFA: sum of polyunsaturated fatty acids; $\Sigma$ n-6: sum of omega-6 fatty acids; $\Sigma$ n-3: sum of omega-3 fatty acids; $\Sigma$ PUFA/ $\Sigma$ SFA: sum of polyunsaturated fatty acids/sum of saturated fatty acids ratio; $\Sigma \mathrm{n}-6 / \Sigma \mathrm{n}-3$ : sum of omega-6/sum of omega-3 ratio.

Source: Authors (2021).

Observe in Table 3 that no significant difference by t-test $(P<0.05)$ was observed among proximate diets composition, ensuring the desirable characteristic of being isoproteic, isocaloric, and isolipidic diets (NRC, 1983). 
Still in Table 3, is possible to compare the fatty acid composition in diets provided to zebrafish. Both diets presented the same fatty acids in their constitution, but with different concentrations for some, especially 18:3n-3. The high concentration of n-3 fatty acids in linseed oil, which is about twenty times higher than in sunflower oil, justified their choice. Consequently, the n-6/n-3 ratio is better adjusted in the diet with linseed oil, which is close to 1 , as indicated by researchers (DiNicolantonio \& OKeefe, 2019). The adjustment of 18:2n-6 and 18:3n-3 amounts is beneficial to the organism because there will be no priority for a single synthetic route of essential fatty acids, such as 20:4n-6, 20:5n-3, and 22:6n-3, for example (Metherel et al., 2017).

When modifying the diet, there must be enough time for it to establish the maximum transfer of bioactive from the feed to the fish, being that period of forty days (Bonafé et al., 2013; Morais et al.; 2012). During this period, one group of fish continued to be fed with sunflower oil, serving as experimental control, while the other group was fed the feed with linseed oil. Thus, it was possible to evaluate the difference in the incorporation of essential fatty acids, focusing on the supplementation of linseed oil.

\subsection{Zebrafish fatty acids quantification}

For more specific results, quantification of the zebrafish fatty acids, after the forty-day treatment, was performed separately in different parts (head, eye, and muscle tissue). These results are listed in Table 4.

Table 4. Fatty acids quantification from head, eyes, and muscle tissue of zebrafish after 40 days of treatment with sunflower and linseed oils (mmol of fatty acid $\mathrm{g}^{-1}$ of sample).

\begin{tabular}{|c|c|c|c|c|c|c|c|}
\hline \multirow[b]{2}{*}{ PCA order } & \multirow[b]{2}{*}{$\begin{array}{l}\text { Fatty } \\
\text { acids }\end{array}$} & \multicolumn{2}{|c|}{ Head } & \multicolumn{2}{|c|}{ Eyes } & \multicolumn{2}{|c|}{ Muscle tissue } \\
\hline & & Sunflower & Linseed & Sunflower & Linseed & Sunflower & Linseed \\
\hline 1 & $15: 0$ & $1.21 *(1.61)$ & $0.59(1.33)$ & $0.31(2.50)$ & $0.31(3.75)$ & $0.16 *(0.30)$ & $0.12(0.30)$ \\
\hline 2 & $16: 0$ & $45.10 *(3.95)$ & $32.10(6.06)$ & $21.40(1.72)$ & $23.30 *(0.95)$ & $7.15 *(1.30)$ & $6.26(0.45)$ \\
\hline 3 & $16: 1 n-9$ & $0.37(1.00)$ & $2.65 *(2.81)$ & $1.53(3.15)$ & $1.72 *(1.73)$ & $0.19 *(0.50)$ & $0.15(0.40)$ \\
\hline 4 & $16: 1 n-7$ & $0.97 *(1.15)$ & $0.79(3.52)$ & $0.41(0.91)$ & $0.45 *(0.83)$ & $0.45(0.53)$ & $0.60 *(1.44)$ \\
\hline 5 & $17: 0$ & $1.16 *(3.03)$ & $0.81(1.34)$ & $0.42(3.38)$ & $0.42(3.85)$ & $0.18 *(0.50)$ & $0.14(0.20)$ \\
\hline 6 & $18: 0$ & $11.30 *(1.48)$ & $8.29(1.09)$ & $7.25(0.93)$ & $8.39 *(0.80)$ & $1.88 *(0.30)$ & $1.71(1.21)$ \\
\hline 7 & $18: 1 n-9$ & $57.50 *(1.08)$ & $43.30(1.17)$ & $30.80(1.10)$ & $32.70 *(0.83)$ & $10.60 *(2.10)$ & $9.39(0.76)$ \\
\hline 8 & $18: 1 n-7$ & $2.47 *(1.36)$ & $1.82(3.40)$ & $1.25(0.81)$ & $1.25(2.43)$ & $0.44 *(0.20)$ & $0.41(0.60)$ \\
\hline 9 & $18: 2 n-6$ & $36.60 *(1.02)$ & $31.60(2.69)$ & $20.20(1.68)$ & $22.00 *(1.09)$ & $8.23 *(1.23)$ & $7.55(0.54)$ \\
\hline 10 & $18: 3 n-6$ & - & - & - & - & $2.74 *(0.40)$ & $0.24(0.30)$ \\
\hline 11 & $18: 3 n-3$ & $5.62(1.28)$ & $5.51(4.34)$ & $1.95(0.53)$ & $3.80 *(0.63)$ & $10.30(0.33)$ & $15.50 *(1.50)$ \\
\hline 12 & $20: 0$ & $0.61 *(2.01)$ & $0.18(1.00)$ & $0.18(3.66)$ & $0.22(2.48)$ & $0.12 *(0.10)$ & $0.09(0.10)$ \\
\hline 13 & $20: 1 n-9$ & $0.93 *(2.08)$ & $0.46(1.33)$ & $0.37(8.33)$ & $0.40(0.31)$ & $0.09(0.80)$ & $0.09(1.00)$ \\
\hline 14 & $20: 2 n-6$ & - & - & - & - & $0.06(0.20)$ & $0.21 *(0.27)$ \\
\hline 15 & $20: 4 n-6$ & $2.96 *(1.06)$ & $1.86(3.77)$ & $1.26 *(2.50)$ & $1.16(2.16)$ & $0.47 *(0.10)$ & $0.31(0.61)$ \\
\hline 16 & $20: 5 n-3$ & $1.01 *(1.87)$ & $0.60(2.10)$ & $0.41(1.64)$ & $0.48 *(0.20)$ & $2.09(0.71)$ & $2.72 *(0.50)$ \\
\hline 17 & $21: 0$ & $2.00 *(1.47)$ & $1.32(1.33)$ & $0.91(1.61)$ & $0.88(1.33)$ & $0.35 *(0.10)$ & $0.09(1.20)$ \\
\hline 18 & $22: 4 n-6$ & $0.35(2.50)$ & $0.35(1.67)$ & $0.20(2.85)$ & $0.23 *(2.50)$ & $0.09(0.92)$ & $0.46 *(0.11)$ \\
\hline 19 & $22: 5 n-6$ & $0.49 *(1.76)$ & $0.23(3.05)$ & $0.17 *(3.33)$ & $0.15(1.20)$ & $0.12 *(0.10)$ & $0.09(0.60)$ \\
\hline 20 & $22: 6 n-3$ & $2.49(1.17)$ & $2.43(1.62)$ & $3.60(0.73)$ & $4.88 *(0.60)$ & $5.58(0.11)$ & $6.20 *(0.78)$ \\
\hline 21 & $24: 0$ & $0.34(2.50)$ & $0.51 *(1.05)$ & $0.14(1.40)$ & $0.20 *(2.85)$ & $0.09(0.10)$ & $0.09(0.30)$ \\
\hline
\end{tabular}


Research, Society and Development, v. 10, n. 16, e113101623177, 2021

(CC BY 4.0) | ISSN 2525-3409 | DOI: http://dx.doi.org/10.33448/rsd-v10i16.23177

\begin{tabular}{|c|c|c|c|c|c|c|c|}
\hline A & $\Sigma$ SFA & $61.72 *(3.25)$ & $43.80(4.32)$ & $30.61(3.42)$ & $33.72 *(2.55)$ & $9.93^{*}(2.48)$ & $8.50(3.27)$ \\
\hline B & $\Sigma$ MUFA & $62.24 *(4.28)$ & $49.02(3.21)$ & $34.36(2.25)$ & $36.52 *(3.24)$ & $11.77 *(2.21)$ & $10.64(4.23)$ \\
\hline $\mathrm{D}$ & $\Sigma \mathrm{n}-6$ & $40.40 *(2.48)$ & 34.04 (3.62) & $21.83(4.27)$ & $23.54 *(1.79)$ & $11.71 *(3.21)$ & $8.86(3.12)$ \\
\hline $\mathrm{E}$ & $\Sigma \mathrm{n}-3$ & $9.12 *(1.22)$ & $8.54(1.24)$ & $5.96(1.86)$ & $9.16^{*}(1.95)$ & 17.97 (1.78) & $24.42 *(2.48)$ \\
\hline G & $\Sigma \mathrm{n}-6 / \Sigma \mathrm{n}-3$ & $4.43 *(2.28)$ & $3.98(3.25)$ & $3.66 *(3.68)$ & $2.57(3.27)$ & $0.65^{*}(2.36)$ & $0.36(2.94)$ \\
\hline
\end{tabular}

Results expressed as mean (coefficient of variation; \%) for analysis in three replicates. * Means with a significant difference by t-test (P < 0.05$)$. $\Sigma$ SFA: sum of saturated fatty acids; $\Sigma$ MUFA: sum of monounsaturated fatty acids; $\Sigma$ PUFA: sum of polyunsaturated fatty acids; $\Sigma$ n-6: sum of omega- 6 fatty acids; $\Sigma$-3: sum of omega-3 fatty acids; $\Sigma$ PUFA/ $\Sigma$ SFA: sum of polyunsaturated fatty acids/sum of saturated fatty acids ratio; $\Sigma$ n6/5n-3: sum of omega-6/sum of omega-3 ratio.

Source: Authors (2021).

A total of 21 fatty acids were identified. Among it, the most abundant fatty acids were: 16:0 (saturated fatty acid; SFA), 18:1n-9 (monounsaturated fatty acid; MUFA), 18:2n-6, and 18:3n-3 (polyunsaturated fatty acid; PUFA), coherently with results published by other researchers (Li et al., 2009; Monroig et al., 2012). However, comparing the results, some fatty acids were significantly altered, proving the efficiency of the bioactive incorporation, according to the different compositions of the feeds. A more embrace analysis of the results was performed using PCA, in order to visualize significant correlations between the results and the zebrafish parts that better incorporated essential fatty acids.

\subsection{PCA analysis}

PCA decomposes the data into separate sets of scores and loadings for the samples and variables, and the whole data variability is explained to provide a clear and more interpretable visualization of data structure in a reduced dimension.

It was used a 6 × 21 data set. The three zebrafish parts (head, eye, and muscle tissue) who received different treatments (fed with sunflower oil or linseed oil) constituted the rows of the matrix; the columns consisted of the mean content for each variable investigated, i.e., each result of fatty acids quantification. The two principal components explained $87.03 \%$ of all variance in the data. The entire data set was shown in Figure 1. 
Figure 1. (1-A) PCA graph from results of scores. SMT: muscle tissue of fish fed with sunflower oil, LMT: muscle tissue of fish fed with linseed oil, SE: eyes of fish fed with sunflower oil, LE: eyes of fish fed with linseed oil, SH: heads of fish fed with sunflower oil, LH: heads of fish fed with linseed oil. (1-B) PCA graph from results of loadings. Numbers refer to fatty acids: 15:0 (1), 16:0 (2), 16:1n-9 (3), 16:1n-7 (4), 17:0 (5), 18:0 (6), 18:1n-9 (7), 18:1n-7 (8), 18:2n-6 (9), 18:3n-6 (10), 18:3n3 (11), 20:0 (12), 20:1n-9 (13), 20:2n-6 (14), 20:4n-6 (15), 20:5n-3 (16), 21:0 (17), 22:4n-6 (18), 22:5n-6 (19), 22:6n-3 (20), 24:0 (21).

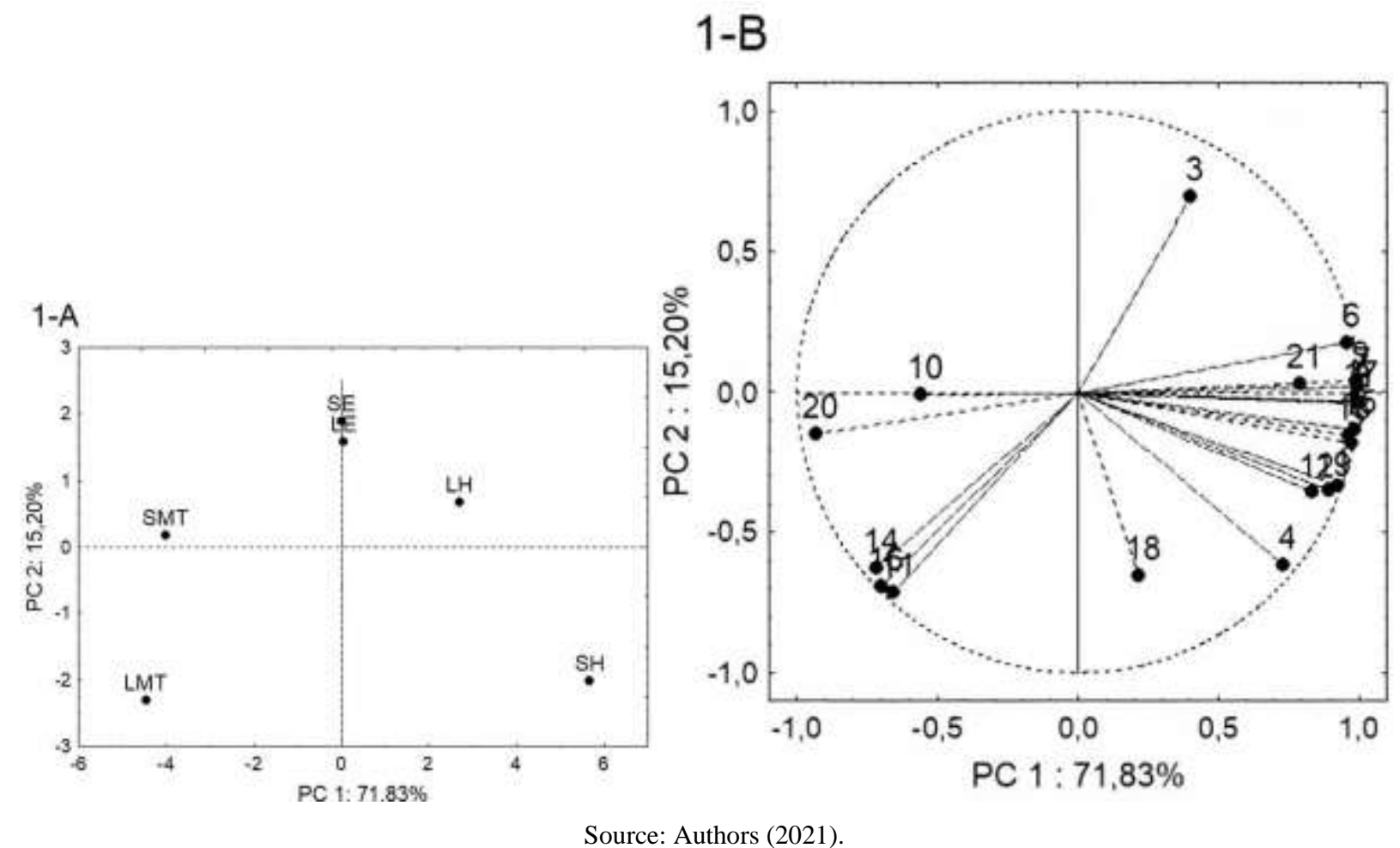

In Figure 1-A, the image with scores (samples) showed the grouping of similar parts of the zebrafish that receive different treatments. Three main groups were formed: group 1 composed of SMT and LMT (muscle tissue of fish fed with sunflower oil and linseed oil, respectively), group 2 composed of SE and LE (eyes of fish fed with sunflower oil and linseed oil, respectively), and group 3 composed of SH and LH (heads of fish fed with sunflower oil and linseed oil, respectively).

Among them, group 1 showed to be strongly correlated with fatty acids 11, 16, and 20 (18:3n-3, 20:5n-3 e 22:6n-3, respectively), being the majority in the muscle tissue, especially in the fish that received the treatment with linseed oil. Due to the high incorporation of 18:3n-3, there is consequently favoring the production of 20:5n-3 and 22:6n-3 by the performance of enzymes that promote the synthesis thereof. As n-3 fatty acids are related to the prevention and cure of various diseases, linseed oil-based nutrition has been shown to be healthier for the zebrafish (Djuricic \& Calder, 2021; Lordan et al., 2020).

The PCA analysis of a second matrix (6 x 7 data set) was also performed. This served to correlate the zebrafish parts that received the different treatments with the information of $\Sigma$ SFA, $\Sigma$ MUFA, $\Sigma$ PUFA, $\Sigma$ n- $6, \Sigma$ n-3, $\Sigma$ PUFA/ $\Sigma$ SFA e $\Sigma$ $6 / \Sigma n-3$. The choice for not correlating all the results in only one matrix was determinant for generating cleaner PCA graphs. Thus, facilitating the visualization of the elements that make up the image. The two principal components explained $99.14 \%$ of all variance in the data. The entire data set was shown in Figure 2. 
Figure 2: (2-A) PCA graph from results of scores. SMT: muscle tissue of fish fed with sunflower oil, LMT: muscle tissue of fish fed with linseed oil, SE: eyes of fish fed with sunflower oil, LE: eyes of fish fed with linseed oil, SH: heads of fish fed with sunflower oil, LH: heads of fish fed with linseed oil. (2-B) PCA graph from results of loadings. Letters refer to: $\Sigma$ SFA (A), $\Sigma$ MUFA (B), $\Sigma$ PUFA (C), $\Sigma$ n-6 (D), $\Sigma$ n-3 (E), $\Sigma$ PUFA/ $\Sigma$ SFA (F), $\Sigma$ n- $6 / \Sigma \mathrm{n}-3$ (G).

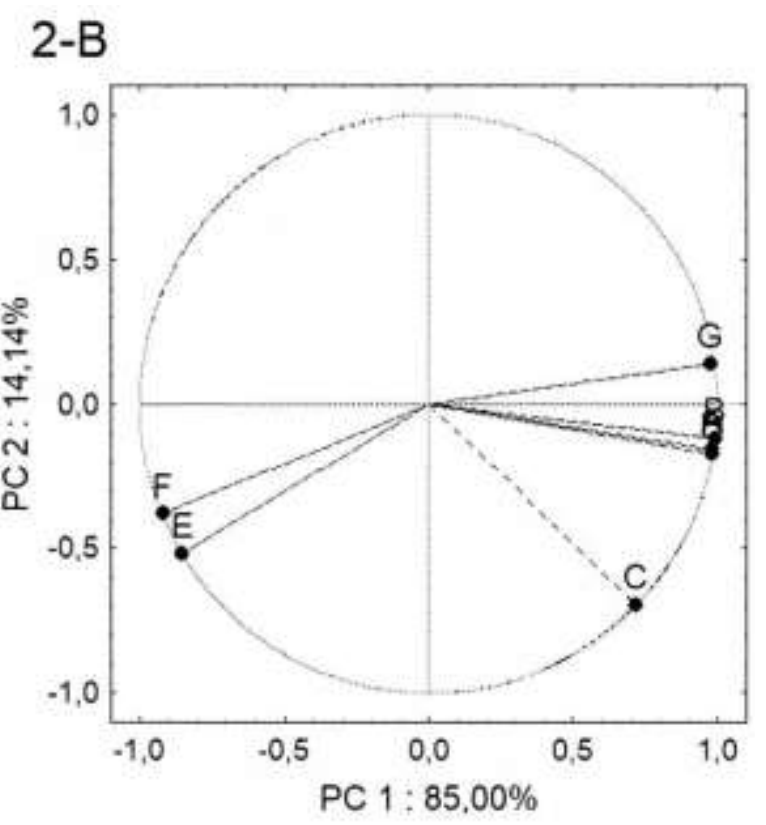

Source: Authors (2021).

In Figure 2-A it is possible to observe clusters similar to that of Figure 1-A, and this is being desirable since it demonstrates that the results are well correlated. Also, in Figure 2 it is possible to correlate group 1 (SMT and LMT) with the answers $\mathrm{E}$ and $\mathrm{F}$, which correspond to $\Sigma \mathrm{n}-3$ and $\Sigma \mathrm{PUFA} / \Sigma \mathrm{SFA}$. This observation agrees with the previous discussion relating group 1 to the concentrations of fatty acids 18:3n-3, 20:5n-3 e 22:6n-3. In addition, the higher sum of PUFA and the smallest sum of SFA caused that the higher $\Sigma$ PUFA/ $\Sigma$ SFA, especially in the LMT sample.

In group 2 (SE and LE), linseed oil treatment also significantly improved the levels of $\Sigma$ PUFA, $\Sigma$ n-3 (18:3n-3 and 22:6n-3, mainly), as well as decreased $\Sigma \mathrm{n}-6 / \Sigma \mathrm{n}-3$. In group 3 (SH and LH), treatment with linseed oil was also advantageous, as it decreased $\Sigma$ SFA (16:0, 18:0 and 20:0, mainly), consequently also improving $\Sigma$ PUFA/ $\Sigma$ SFA. However, $\Sigma$ n-3 was not significantly altered.

\subsection{Gene expression analysis}

The quantitative real-time PCR expression of desaturase and elongase genes after normalization against $\beta$-actin in liver tissue from zebrafish did not present a significant difference in the results. Thus, it was noted that dietary substitution did not alter fish metabolism.

Vertebrates have a complex synthase and metabolism of fatty acids. Dietary fatty acids regulate gene expression in the liver (Pang et al., 2014). Zebrafish is a model fish species, which presented great capacity to biosynthesize fatty acids with long-chain - PUFA (C20 and C24) from vegetable oil-derived C18 dietary precursors (Agaba et al., 2004; Hastings et al., 2001). In this research was observed 22:6n-3 accumulation in eyes and muscle tissue of group fed with a diet rich in 18:3n-3 (linseed oil), probably due to endogenous $18: 3 n-3$, which is highly sensitive to substrate concentration.

$\Delta 6$-desaturase is a fatty acid metabolic enzyme, which uses 18:3n-3 as substrate to convert 20:5n-3 and 22:6n-3 (Yoshizaki et al., 2005). Pang et al. (2014) in a phylogenetic analysis indicates that the zebrafish sequence has the highest 
homology with mammalian $\Delta 6$ desaturases. Elongation that adds carbon to the chain occurs via elongase enzyme, which indicated a regulatory role on long chain - PUFA synthesis (Tu et al., 2010). ${ }^{40}$

Jaya-Ram et al. (2008) observed elevated transcription of liver desaturase and elongase genes with the inclusion of dietary linseed oil. Suggesting that the principal mechanism for increased PUFA biosynthesis during limited dietary PUFA intake is through up-regulated expression of mRNA of these enzymes. So, dietary PUFA may exert its influences on desaturation and elongation activities by two actions: directly through modification of cellular membrane fluidity, and via regulation of transcription factors essential for activation or repression of both desaturase and elongase genes.

Taken together, these results shed a light for fish farmers and feed manufactures interested in functional foods. New studies can be conducted with other fish species generally consumed in western and eastern diets to further substantiate the results acquired in this study. Besides, the effect of fish consumption on the human organism has been thoroughly investigated by previous studies, hence further studies reporting new ways of enhancing the product lipid quality is extremely important.

\section{Final Considerations}

Linseed oil was chosen as a substitute for sunflower oil due to its rich n-3 lipid profile. The linseed supplemented diet was well accepted by zebrafish, essential fatty acids were incorporated into the parts being evaluated, and lipid quality of the meat was significantly improved. Muscle tissue more easily incorporated n-3 fatty acids, particularly 18:3n-3, enabling biosynthesis of essential fatty acids without causing unwanted metabolic changes. The current work demonstrated that essential fatty acids synthesis, especially those in the omega-3 family, is enhanced by consumption of a diet supplemented with linseed oil. New studies should be performed with other fish species generally consumed by human to assess the impact of diet in other products since improvement of food quality of fish meat positively affects human health.

\section{Acknowledgments}

The authors would like to thank CAPES, CNPQ, and Fundação Araurcária for their financial support.

\section{References}

Adel, S., Heydeck, D., Kuhn, H., \& Ufer, C. (2016). The lipoxygenase pathway in zebrafish. Expression and characterization of zebrafish ALOX5 and comparison with its human ortholog. Biochimica et Biophysica Acta (BBA)-Molecular and Cell Biology of Lipids, 1861(1), 1-11.. https://doi.org/10.1016/j.bbalip.2015.10.001

Agaba, M., Tocher, D. R., Dickson, C. A., Dick, J. R., \& Teale, A. J. (2004). Zebrafish cDNA encoding multifunctional fatty acid elongase involved in production of eicosapentaenoic (20: 5n-3) and docosahexaenoic (22: 6n-3) acids. Marine Biotechnology, 6(3), 251-261. https://doi.org/10.1007/s10126-0030029-1

AOAC, 2000. Official methods of analysis 17th Ed. Association of official analytical chemists. Arlington, VA, USA.

Balić, A., Vlašić, D., Žužul, K., Marinović, B., \& Bukvić Mokos, Z. (2020). Omega-3 versus omega-6 polyunsaturated fatty acids in the prevention and treatment of inflammatory skin diseases. International journal of molecular sciences, 21(3), 741. https://doi.org/10.3390/ijms21030741

Bligh, E. G., \& Dyer, W. J. (1959). A rapid method of total lipid extraction and purification. Canadian journal of biochemistry and physiology, 37(8), 911-917. https://doi.org/10.1139/o59-099

Bonafé, E. G., Boeing, J. S., Matsushita, M., Claus, T., de Oliveira Santos, O., de Oliveira, C. C., ... \& Visentainer, J. V. (2013). Evaluation of conjugated fatty acids incorporation in tilapia through GC-FID and EASI-MS. European Journal of Lipid Science and Technology, 115(10), 1139-1145. https://doi.org/10.1002/ejlt.201300032

Broughton, R., Tocher, D. R., \& Betancor, M. B. (2020). Development of a C18 Supercritical Fluid Chromatography-Tandem Mass Spectrometry Methodology for the Analysis of Very-Long-Chain Polyunsaturated Fatty Acid Lipid Matrices and Its Application to Fish Oil Substitutes Derived from Genetically Modified Oilseeds in the Aquaculture Sector. ACS omega, 5(35), 22289-22298. https://doi.org/10.1021/acsomega.0c02631

Canedo, A., \& Rocha, T. L. (2020). Zebrafish (Danio rerio) using as model for genotoxicity and DNA repair assessments: Historical review, current status and trends. Science of The Total Environment, 144084. https://doi.org/10.1016/j.scitotenv.2020.144084 
Carbonera, F., Montanher, P. F., Palombini, S. V., Maruyama, S. A., Claus, T., Santos, H., ... \& Visentainer, J. V. (2014). Antioxidant capacity in tilapia fillets enriched with extract of acerola fruit residue. Journal of the Brazilian Chemical Society, 25(7), 1237-1245. http://doi.org/10.5935/0103-5053.20140101

DiNicolantonio, J. J., \& OKeefe, J. (2019). Importance of maintaining a low omega-6/omega-3 ratio for reducing platelet aggregation, coagulation and thrombosis. http://dx.doi.org/10.1136/openhrt-2019-001011

Djuricic, I., \& Calder, P. C. (2021). Beneficial outcomes of omega-6 and omega-3 polyunsaturated fatty acids on human health: An update for 2021. Nutrients, 13(7), 2421. https://doi.org/10.3390/nu13072421

Figueiredo, I. L., Claus, T., Júnior, O. O. S., Almeida, V. C., Magon, T., \& Visentainer, J. V. (2016). Fast derivatization of fatty acids in different meat samples for gas chromatography analysis. Journal of Chromatography A, 1456, 235-241. https://doi.org/10.1016/j.chroma.2016.06.012

Gammone, M. A., Riccioni, G., Parrinello, G., \& D’Orazio, N. (2019). Omega-3 polyunsaturated fatty acids: benefits and endpoints in sport. Nutrients, 11(1), 46. https://doi.org/10.3390/nu11010046

Hastings, N., Agaba, M., Tocher, D. R., Leaver, M. J., Dick, J. R., Sargent, J. R., \& Teale, A. J. (2001). A vertebrate fatty acid desaturase with $\Delta 5$ and $\Delta 6$ activities. Proceedings of the National Academy of Sciences, 98(25), 14304-14309. https://doi.org/10.1073/pnas.251516598

Jaya-Ram, A., Kuah, M. K., Lim, P. S., Kolkovski, S., \& Shu-Chien, A. C. (2008). Influence of dietary HUFA levels on reproductive performance, tissue fatty acid profile and desaturase and elongase mRNAs expression in female zebrafish Danio rerio. Aquaculture, 277(3-4), 275-281. https://doi.org/10.1016/j.aquaculture.2008.02.027

Li, J., Yue, Y., Li, T., Hu, X., \& Zhong, H. (2009). Gas chromatography-mass spectrometric analysis of bonded long chain fatty acids in a single zebrafish egg by ultrasound-assisted one-step transmethylation and extraction. Analytica chimica acta, 650(2), 221-226. https://doi.org/10.1016/j.aca.2009.07.045

Livak, K. J., \& Schmittgen, T. D. (2001). Analysis of relative gene expression data using real-time quantitative PCR and the $2-\Delta \Delta C T$ method. methods, 25(4), 402-408. https://doi.org/10.1006/meth.2001.1262

Lordan, R., Redfern, S., Tsoupras, A., \& Zabetakis, I. (2020). Inflammation and cardiovascular disease: are marine phospholipids the answer?. Food \& function, 11(4), 2861-2885. https://doi.org/10.1039/C9FO01742A

Metherel, A. H., Chouinard-Watkins, R., Trépanier, M. O., Lacombe, R. S., \& Bazinet, R. P. (2017). Retroconversion is a minor contributor to increases in eicosapentaenoic acid following docosahexaenoic acid feeding as determined by compound specific isotope analysis in rat liver. Nutrition \& metabolism, 14(1), 1-8. https://doi.org/10.1186/s12986-017-0230-2

Monroig, Ó., Guinot, D., Hontoria, F., Tocher, D. R., \& Navarro, J. C. (2012). Biosynthesis of essential fatty acids in Octopus vulgaris (Cuvier, 1797): Molecular cloning, functional characterisation and tissue distribution of a fatty acyl elongase. Aquaculture, 360, 45-53. https://doi.org/10.1016/j.aquaculture.2012.07.016

Morais, S., Castanheira, F., Martinez-Rubio, L., Conceição, L. E., \& Tocher, D. R. (2012). Long chain polyunsaturated fatty acid synthesis in a marine vertebrate: ontogenetic and nutritional regulation of a fatty acyl desaturase with $\Delta 4$ activity. Biochimica et Biophysica Acta (BBA)-Molecular and Cell Biology of Lipids, 1821(4), 660-671. https://doi.org/10.1016/j.bbalip.2011.12.011

Nehra, M., Nain, K. B., Malik, A., Mohsin, M., \& Gill, A. (2020). Enrichment of Essential Fatty Acids in Food. In Essential Fatty Acids (pp. 157-182). CRC Press.

NRC - Nutrient requirements of warm water fishes and shellfishes. National Academy Press, Washington.1983.

Pang, S. C., Wang, H. P., Li, K. Y., Zhu, Z. Y., Kang, J. X., \& Sun, Y. H. (2014). Double transgenesis of humanized fat1 and fat2 genes promotes omega-3 polyunsaturated fatty acids synthesis in a zebrafish model. Marine biotechnology, 16(5), 580-593. https://doi.org/10.1007/s10126-014-9577-9

Pérez, J. A., Castro, A., Rolo, C., Torres, A., Dorta-Guerra, R., Acosta, N. G., \& Rodríguez, C. (2021). Fatty acid profiles and omega-3 LC-PUFA biosynthesis capacity of three dual purpose chicken breeds. Journal of Food Composition and Analysis, 104005. https://doi.org/10.1016/j.jfca.2021.104005

Pérez-Palacios, T., Ruiz-Carrascal, J., Solomando, J. C., \& Antequera, T. (2019). Strategies for enrichment in $\omega$-3 fatty acids aiming for healthier meat products. Food Reviews International, 35(5), 485-503. https://doi.org/10.1080/87559129.2019.1584817

Perini, J. Â. D. L., Stevanato, F. B., Sargi, S. C., Visentainer, J. E. L., Dalalio, M. M. D. O., Matshushita, M., ... \& Visentainer, J. V. (2010). Omega-3 and omega-6 polyunsaturated fatty acids: metabolism in mammals and immune response. Revista de Nutrição, 23(6), 1075-1086. http://doi.org/10.1590/S141552732010000600013

Sargi, S. C., Silva, B. C., Santos, H. M. C., Montanher, P. F., Boeing, J. S., Santos Júnior, O. O., ... \& Visentainer, J. V. (2013). Antioxidant capacity and chemical composition in seeds rich in omega-3: chia, flax, and perilla. Food Science and Technology, 33, 541-548. http://doi.org/10.1590/S010120612013005000057

Simopoulos, A. P., Serhan, C. N., \& Bazinet, R. P. (2021). The need for precision nutrition, genetic variation and resolution in Covid-19 patients. Molecular Aspects of Medicine, 100943. https://doi.org/10.1016/j.mam.2021.100943

Stevens, C. H., Reed, B. T., \& Hawkins, P. (2021). Enrichment for laboratory zebrafish-a review of the evidence and the challenges. Animals, 11(3), 698. https://doi.org/10.3390/ani11030698

Tu, W. C., Cook-Johnson, R. J., James, M. J., Mühlhäusler, B. S., \& Gibson, R. A. (2010). Omega-3 long chain fatty acid synthesis is regulated more by substrate levels than gene expression. Prostaglandins, Leukotrienes and Essential Fatty Acids, 83(2), 61-68. https://doi.org/10.1016/j.plefa.2010.04.001

Verma, S. K., Nandi, A., Sinha, A., Patel, P., Jha, E., Mohanty, S., ... \& Suar, M. (2021). Zebrafish (Danio rerio) as an ecotoxicological model for Nanomaterial induced toxicity profiling. Precis. Nanomed. https://doi.org/10.33218/001c.21978 
Research, Society and Development, v. 10, n. 16, e113101623177, 2021

(CC BY 4.0) | ISSN 2525-3409 | DOI: http://dx.doi.org/10.33448/rsd-v10i16.23177

Visentainer, J. V. (2012). Aspectos analíticos da resposta do detector de ionização em chama para ésteres de ácidos graxos em biodiesel e alimentos. Química Nova, 35, 274-279. http://doi.org/10.1590/S0100-40422012000200008

Yoshizaki, G., Kiron, V., Satoh, S., \& Takeuchi, T. (2005). Enhancement of EPA and DHA biosynthesis by over-expression of masu salmon $\Delta 6$-desaturaselike gene in zebrafish. Transgenic research, 14(2), 159-165. https://doi.org/ 10.1007/s11248-004-7435-7

Zhang, M., Chen, C., You, C., Chen, B., Wang, S., \& Li, Y. (2019). Effects of different dietary ratios of docosahexaenoic to eicosapentaenoic acid (DHA/EPA) on the growth, non-specific immune indices, tissue fatty acid compositions and expression of genes related to LC-PUFA biosynthesis in juvenile golden pompano Trachinotus ovatus. Aquaculture, 505, 488-495. https://doi.org/10.1016/j.aquaculture.2019.01.061

Zhukova, N. V. (2019). Fatty acids of marine mollusks: Impact of diet, bacterial symbiosis and biosynthetic potential. Biomolecules, 9(12), 857. https://doi.org/10.3390/biom9120857 